\title{
Snow depth, soil freezing, and fluxes of carbon dioxide, nitrous oxide and methane in a northern hardwood forest
}

\author{
PETER M. GROFFMAN*, JANET P. HARDY $\dagger$, CHARLES T. DRISCOLL $\ddagger$ and \\ TIMOTHY J. FAHEY \\ *Institute of Ecosystem Studies, Box AB, Millbrook, NY 12545, USA, †US Army, Cold Regions Research and Engineering \\ Laboratory, Hanover, NH 03755, USA, †Department of Civil and Environmental Engineering, Syracuse University, Syracuse, \\ NY 13244, USA, §Department of Natural Resources, Cornell University, Ithaca, NY 14853, USA
}

\begin{abstract}
Soil-atmosphere fluxes of trace gases (especially nitrous oxide $\left(\mathrm{N}_{2} \mathrm{O}\right)$ ) can be significant during winter and at snowmelt. We investigated the effects of decreases in snow cover on soil freezing and trace gas fluxes at the Hubbard Brook Experimental Forest, a northern hardwood forest in New Hampshire, USA. We manipulated snow depth by shoveling to induce soil freezing, and measured fluxes of $\mathrm{N}_{2} \mathrm{O}$, methane $\left(\mathrm{CH}_{4}\right)$ and carbon dioxide $\left(\mathrm{CO}_{2}\right)$ in field chambers monthly (bi-weekly at snowmelt) in stands dominated by sugar maple or yellow birch. The snow manipulation and measurements were carried out in two winters (1997/1998 and 1998/1999) and measurements continued through 2000. Fluxes of $\mathrm{CO}_{2}$ and $\mathrm{CH}_{4}$ showed a strong seasonal pattern, with low rates in winter, but $\mathrm{N}_{2} \mathrm{O}$ fluxes did not show strong seasonal variation. The snow manipulation induced soil freezing, increased $\mathrm{N}_{2} \mathrm{O}$ flux and decreased $\mathrm{CH}_{4}$ uptake in both treatment years, especially during winter. Annual $\mathrm{N}_{2} \mathrm{O}$ fluxes in sugar maple treatment plots were 207 and $99 \mathrm{mg} \mathrm{N} \mathrm{m}^{-2} \mathrm{yr}^{-1}$ in 1998 and 1999 vs. 105 and 42 in reference plots. Tree species had no effect on $\mathrm{N}_{2} \mathrm{O}$ or $\mathrm{CO}_{2}$ fluxes, but $\mathrm{CH}_{4}$ uptake was higher in plots dominated by yellow birch than in plots dominated by sugar maple. Our results suggest that winter fluxes of $\mathrm{N}_{2} \mathrm{O}$ are important and that winter climate change that decreases snow cover will increase soil:atmosphere $\mathrm{N}_{2} \mathrm{O}$ fluxes from northern hardwood forests.
\end{abstract}

Keywords: carbon dioxide, methane, nitrogen, nitrous oxide, northern hardwood forest, snow, soil freezing, winter climate change

Received 26 January 2005; revised version received 3 December 2005; accepted 20 March 2006

Introduction

While most studies in global change biology have focused on the 'growing season,' there is ample evidence of marked changes in climatic conditions during winter (Likens, 2000; Schwartz \& Reiter, 2000; Dye, 2002; Hodgkins et al., 2003; Wolfe et al., 2005) and that this change has implications for the biogeochemistry of forest ecosystems (Mitchell et al., 1996; Murdoch et al., 1998; Williams et al., 1998). Rates of soil biological processes are surprisingly high in winter, accounting for significant percentages of annual activity, and these processes are sensitive to disturbance of winter climate, especially snow depth and soil freezing (Clein \& Schimel, 1995; Brooks et al., 1996; van Bochove et al.,

Correspondence: Peter M. Groffman, tel. + 845677 7600, fax + 845677 5976, e-mail: groffmanp@ecostudies.org. 2000b; Groffman et al., 2001a; Schimel et al., 2004; Hubbard et al., 2005).

Winter dynamics have been shown to be particularly important for soil-atmosphere fluxes of carbon dioxide $\left(\mathrm{CO}_{2}\right)$, nitrous oxide $\left(\mathrm{N}_{2} \mathrm{O}\right)$ and methane $\left(\mathrm{CH}_{4}\right)$ (Sommerfield et al., 1993; Brooks et al., 1997; Alm et al., 1999; Brumme et al., 1999). In the soil, $\mathrm{CO}_{2}$ is a product of root and microbial respiration, $\mathrm{N}_{2} \mathrm{O}$ is an intermediate product of nitrogen $(\mathrm{N})$ transformations (primarily nitrification and denitrification) and $\mathrm{CH}_{4}$ is produced by anaerobic and consumed by aerobic microorganisms (Mooney et al., 1987). Changes in these fluxes are of interest as they are greenhouse gases, their concentrations are increasing in the atmosphere, and $\mathrm{N}_{2} \mathrm{O}$ plays a role in the destruction of ozone in the stratosphere (Prather et al., 1995).

There has been particular interest in winter fluxes of $\mathrm{N}_{2} \mathrm{O}$ in temperate ecosystems, as much of the annual 
flux appears to occur during winter and during the transition from winter to spring, when freeze-thaw events are common (Brumme et al., 1999; Groffman et al., 2000; Butterbach-Bahl et al., 2002). High fluxes during these periods have been attributed to: (1) reduced plant uptake leading to increased rates of microbial transformations of N (Zak et al., 1990; Groffman et al., 1993), (2) accumulation and release of $\mathrm{N}_{2} \mathrm{O}$ from beneath frozen soil layers (Goodroad \& Keeney, 1984; Burton \& Beauchamp, 1994; van Bochove et al., 2001), (3) freezing-induced microbial mortality followed by rapid regrowth and high rates of microbial transformations of N (Edwards \& Killham, 1986; Christensen \& Tiedje, 1990; DeLuca et al., 1992; Schimel \& Clein, 1996; Brooks et al., 2004; Dörsch et al., 2004) and (4) freezinginduced disruption of soil aggregates and release of available carbon that stimulates denitrification (Groffman \& Tiedje, 1989; van Bochove et al., 2000a). Fluxes of $\mathrm{N}_{2} \mathrm{O}$ are notoriously heterogeneous, however, and there is wide variation in the estimates of the importance of winter fluxes in different ecosystems (Groffman et al., 2000). There have been very few studies assessing the response of these fluxes to variation (either natural or manipulated) in snowpack and soil freezing (Schimel et al., 2004). Fluxes of $\mathrm{CH}_{4}$ have been shown to be sensitive to snowpack properties (Melloh \& Crill, 1996; Borken et al., 2006), but as for $\mathrm{N}_{2} \mathrm{O}$ there have been very few studies of the response of these fluxes to variation in winter conditions.

We have been studying relationships between snow depth, soil freezing and forest biogeochemistry at the Hubbard Brook Experimental Forest (HBEF) in New Hampshire, USA since 1997 (Groffman et al., 2001a). We reduced snow cover by shoveling and monitored changes in soil freezing (Hardy et al., 2001), root dynamics (Tierney et al., 2001), soil solution chemistry (Fitzhugh et al., 2001, 2003) and soil N cycling processes (Groffman et al., 2001b) in forest stands dominated by either sugar maple or yellow birch during the winters of 1997/1998 and 1998/1999. Here, we report soil-atmosphere fluxes of $\mathrm{CO}_{2}, \mathrm{CH}_{4}$ and $\mathrm{N}_{2} \mathrm{O}$ during the two treatment years and for one nontreatment, recovery year (1999/2000). Our objectives were to: (1) quantify annual trace gas fluxes in sugar maple and yellow birch stands at the HBEF, (2) evaluate the importance of winter activity to annual fluxes of these gases and (3) assess the response of these fluxes to variation in soil freezing.

\section{Methods and materials}

\section{Site description and experimental design}

The HBEF is located in the White Mountain National Forest in New Hampshire, USA $\left(43^{\circ} 56^{\prime} \mathrm{N}, 71^{\circ} 45^{\prime} \mathrm{W}\right)$. The northern hardwood forest vegetation is dominated by American beech (Fagus grandiflora), sugar maple (Acer saccharum) and yellow birch (Betula alleghanieusis). The forest was selectively cut in the 1880s and 1910s, and some of the older stands were damaged by a hurricane in 1938. Soils are shallow $(75-100 \mathrm{~cm})$, acidic ( $\mathrm{pH}$ 3.9) Typic Haplorthods developed from unsorted basal tills. Mean air temperature is $18^{\circ} \mathrm{C}$ in July and $-9^{\circ} \mathrm{C}$ in January. Average annual precipitation is $140 \mathrm{~cm}$. A continuous snowpack develops each year to depths of $0.5-1.5 \mathrm{~m}$. Maximum snow water equivalence usually occurs mid-March followed by 1-2 months of snowmelt, depending on aspect and elevation.

The snow manipulation study (described in detail in Groffman et al., 2001a) took place within four stands; two dominated by sugar maple and two dominated by yellow birch ( $80 \%$ dominance by the target species). There were eight, $10 \mathrm{~m} \times 10 \mathrm{~m}$ plots in this study; with one snow reduction (treatment) and one reference plot located in each of the four stands such that there were two replicates of each vegetation by treatment combination. Plots were instrumented with soil solution samplers (zero tension lysimeters), thermistors for soil temperature monitoring, soil water content monitors (Campbell CS615 water content reflectometers, Campbell Scientific, Logan, UT, USA), frost tubes, minirhizotron access tubes and trace gas flux measurement chambers (described below). All instruments were installed in fall 1996 to allow for any installation-related disturbance effects to subside before the treatment was introduced in fall/winter of 1997.

All plots were equipped with dataloggers to allow for continuous monitoring of soil moisture and temperature. Thermistors measured soil temperatures every $0.1 \mathrm{~m}$ to a depth of $0.5 \mathrm{~m}$ and snow temperatures every $0.2 \mathrm{~m}$ to a height of $0.8 \mathrm{~m}$. We measured snow and soil temperatures every $5 \mathrm{~min}$ and data were stored as hourly averages on a datalogger. Every 2 weeks, we made manual measurements of snow depth variability $(n=100)$, snow density and snow water equivalence at two sites (Hardy et al., 2001).

To manipulate snow depth, shovels were used to clear the treatment plots of snow as soon as practical after each snow event. A few centimeters of snow were left to compact on the ground to protect equipment and the forest floor from shovel damage, and to increase the albedo of the forest floor to aid in soil freezing. The treatment was applied from late November through January in the winters of 1997/1998 and 1998/1999. After February 1, snow was allowed to accumulate on the treatment plots to minimize disturbance of annual water input to the plots. Water removal associated with the treatment was less than $15 \%$ of annual precipitation input (Hardy et al., 2001). Plot measurements (including 
trace gas fluxes) continued through the fall of 2000 to provide for a complete 'recovery year' (1999/2000).

\section{Soil-atmosphere trace gas flux methods}

When plots were snow free, we used the gas flux chamber design described by Bowden et al. (1990, 1991). This design calls for $287 \mathrm{~mm}$ diameter (ID) by $40 \mathrm{~mm}$ high polyvinyl chloride (PVC) cylinder chambers with gas sampling ports in the center of the chamber top. The chambers are placed on top of PVC base rings of the same diameter that are permanently installed $5 \mathrm{~cm}$ into the soil, immediately before measurement. For snow-covered plots, aluminum chambers (approximately $5 \mathrm{~L}$ ) fitted with septa were inserted $5 \mathrm{~cm}$ into the snowpack just before measurement. In all seasons, $9 \mathrm{~mL}$ gas samples were collected using fineneedle polypropylene syringes $0,10,20$ and $30 \mathrm{~min}$ following placement of the chamber on the base. Samples were transferred to evacuated glass vials which were stored at room temperature before analysis by gas chromatography using electron capture detection for $\mathrm{N}_{2} \mathrm{O}$, thermal conductivity detection for $\mathrm{CO}_{2}$ and flame ionization detection for $\mathrm{CH}_{4}$. Fluxes were calculated from the linear rate of change in gas concentration, the chamber internal volume and soil surface area. There were from three to five chambers in each plot. Fluxes were measured weekly during early spring and monthly at other times of the year.

\section{Statistical analysis}

Overall treatment and vegetation type effects were assessed with two-way repeated measures analysis of variance (with interactions) of plot means from each sampling date with treatment and vegetation as main effects. Seasonal values were computed by taking the mean of all sampling dates within a season (DecemberMarch $=$ winter, April-May = spring, June-September = summer, October-November-fall) and multiplying by either 120 days (winter), 71 days (fall, spring) or 90 days (summer). Annual values were computed by summing the seasonal values. Annual flux estimates were analyzed by two-way analysis of variance (with interactions) without repeated measures. Relationships between variables were explored using Pearson's productmoment correlations. The statistical analysis system (SAS, 1989) was used for all analyses.

\section{Results}

Climate data and response to treatment for this study were described in detail by Hardy et al. (2001). Briefly, summer temperatures were comparable with the 30year average, but both treatment snow seasons (1997/ 1998 and 1998/1999), as well as the recovery year (1999/2000) were relatively mild, with average winter (December-March) temperatures of $-2.1,-3.2$ and $-3.2^{\circ} \mathrm{C}$, respectively, compared with a 30 -year average of $-4.7^{\circ} \mathrm{C}$. Maximum snow depths were also below normal, with maximum snow depths of 61, 57 and $64 \mathrm{~cm}$ for the 3 years of the study, compared with an average of $74 \mathrm{~cm}$. Duration of snow cover was also below normal, with 135, 105 and 92 days of cover during the 3 years of the study, compared with an average of 165 days.

The shoveling treatment successfully induced soil freezing in all plots in both years (Table 1). Maximum frost depths ranged from 10 to $50 \mathrm{~cm}$ and treated plots stayed frozen until after snowmelt (Hardy et al., 2001). Winter soil temperatures in the reference plots seldom went below zero, while temperatures in the treatment

Table 1 Maximum snow and frost depth (from Hardy et al., 2001), in situ net $\mathrm{N}$ mineralization and nitrification, and microbial biomass (from Groffman et al., 2001b), proportional overwinter fine root mortality (from Tierney et al., 2001) and nitrate leaching (from Fitzhugh et al., 2001) in treatment and reference plots in 1998 (November 1997-October 1998) and 1999 (November 1998-October 1999)

\begin{tabular}{|c|c|c|c|c|}
\hline & \multicolumn{2}{|l|}{1998} & \multicolumn{2}{|l|}{1999} \\
\hline & Treatment & Reference & Treatment & Reference \\
\hline Maximum snow depth $(\mathrm{cm})$ & $31(6)$ & $76(10)$ & $23(3)$ & $76(7)$ \\
\hline Maximum frost depth $(\mathrm{cm})$ & $28(9)$ & $0(0)$ & $28(4)$ & $4(2)$ \\
\hline Net $\mathrm{N}$ mineralization $\left(\mathrm{g} \mathrm{N} \mathrm{m}^{-2} \mathrm{yr}^{-1}\right)$ & $13.2(2.6)$ & $11.9(1.7)$ & $23.1(1.0)$ & $21.9(3.4)$ \\
\hline Net nitrification $\left(\mathrm{g} \mathrm{N} \mathrm{m}^{-2} \mathrm{yr}^{-1}\right)$ & $8.4(0.9)$ & $7.1(2.3)$ & $13.5(2.5)$ & $12.2(2.9)$ \\
\hline Microbial biomass $\left(\mathrm{mg} \mathrm{C} \mathrm{kg}^{-1}\right)$ & $2376(385)$ & $2359(386)$ & $2171(273)$ & $2162(281)$ \\
\hline Overwinter root mortality & $0.26(0.04)$ & $0.14(0.03)$ & $0.29(0.01)$ & $0.16(0.02)$ \\
\hline Nitrate leaching $\left(\mathrm{mol} \mathrm{ha}^{-1} \mathrm{month}^{-1}\right)^{*}$ & & & $88(13)$ & $31(5)$ \\
\hline
\end{tabular}

*Values are mean monthly leaching flux over both years.

Values are mean (standard error) of four treatment and four reference plots in two sugar maple and two yellow birch stands 
plots remained below zero (but never below $-5^{\circ} \mathrm{C}$ ) throughout the winter. The treatment doubled overwinter root mortality (Tierney et al., 2001) and markedly increased leaching of nitrate $\left(\mathrm{NO}_{3}^{-}\right)$, soluble reactive phosphorus, base cations and hydrogen ions $\left(\mathrm{H}^{+}\right)$ (Fitzhugh et al., 2001, 2003). The treatment had no effect on rates of net $\mathrm{N}$ mineralization or nitrification, suggesting that increased leaching was because of reductions in plant uptake (Groffman et al., 2001b). Net mineralization and nitrification were markedly higher in 1999 than in 1998.

A concern with our trace gas flux measurements was that the need to use different chamber methods for snow-covered and snow-free plots would inhibit our ability to see differences between treatments. While a comprehensive comparison of the two methods is not possible, visual analysis of flux data (Figs 1-3) suggests that the 'over snow' chambers used for snow-covered
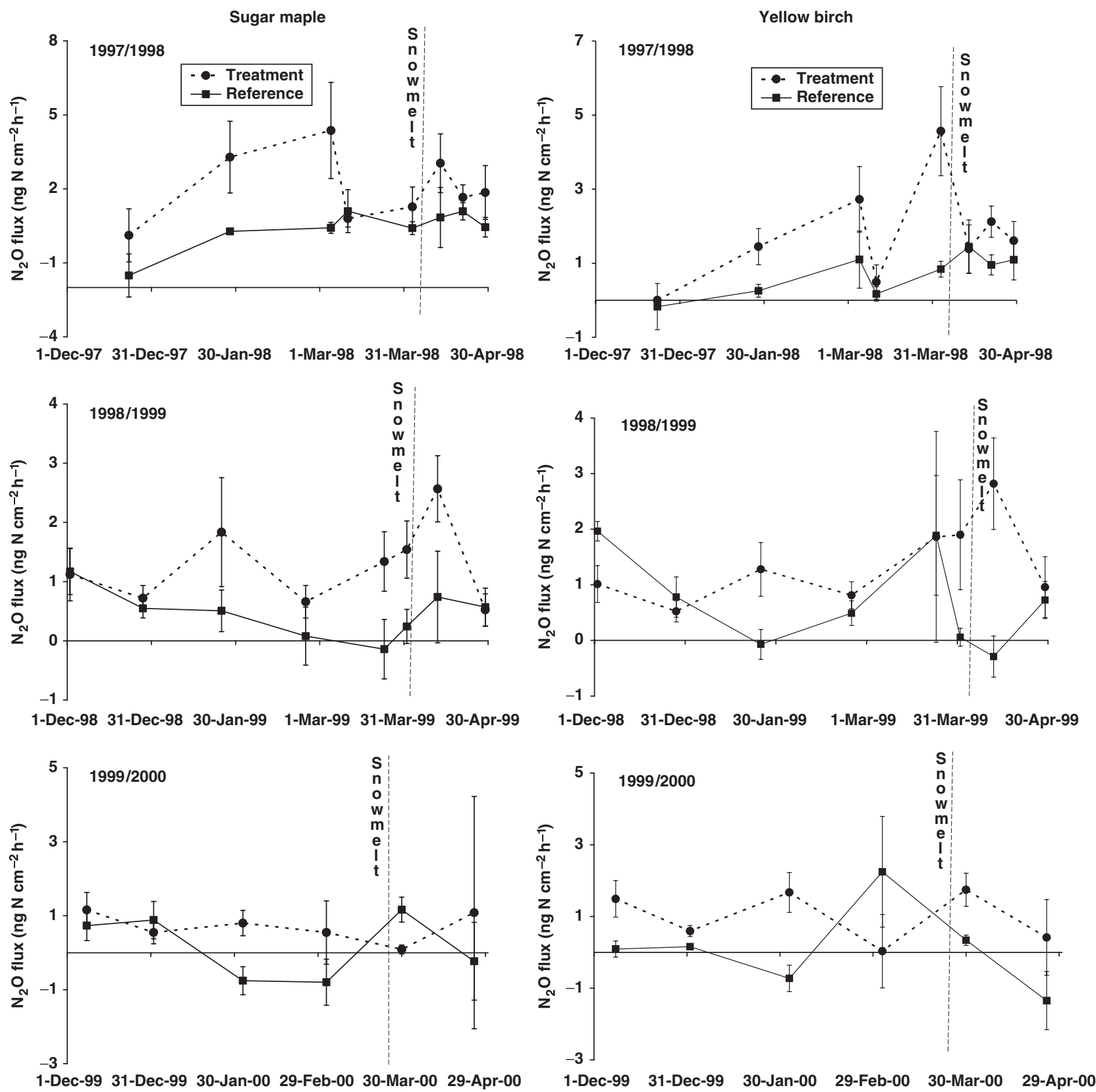

Fig. 1 Nitrous oxide flux in reference and treatment plots in sugar maple (left) and yellow birch (right) stands in the winters of 1997/1998 (top), 1998/1999 (middle) and 1999/2000 (bottom). Shoveling treatments were applied in 1997/1998 and 1998/1999 while $1999 / 2000$ was a nontreatment, 'recovery' year. Values are means of two plots per treatment/vegetation combination $(n=2)$ with standard error. There were three or four flux chambers per plot.

(C) 2006 The Authors

Journal compilation (C) 2006 Blackwell Publishing Ltd, Global Change Biology, 12, 1748-1760 

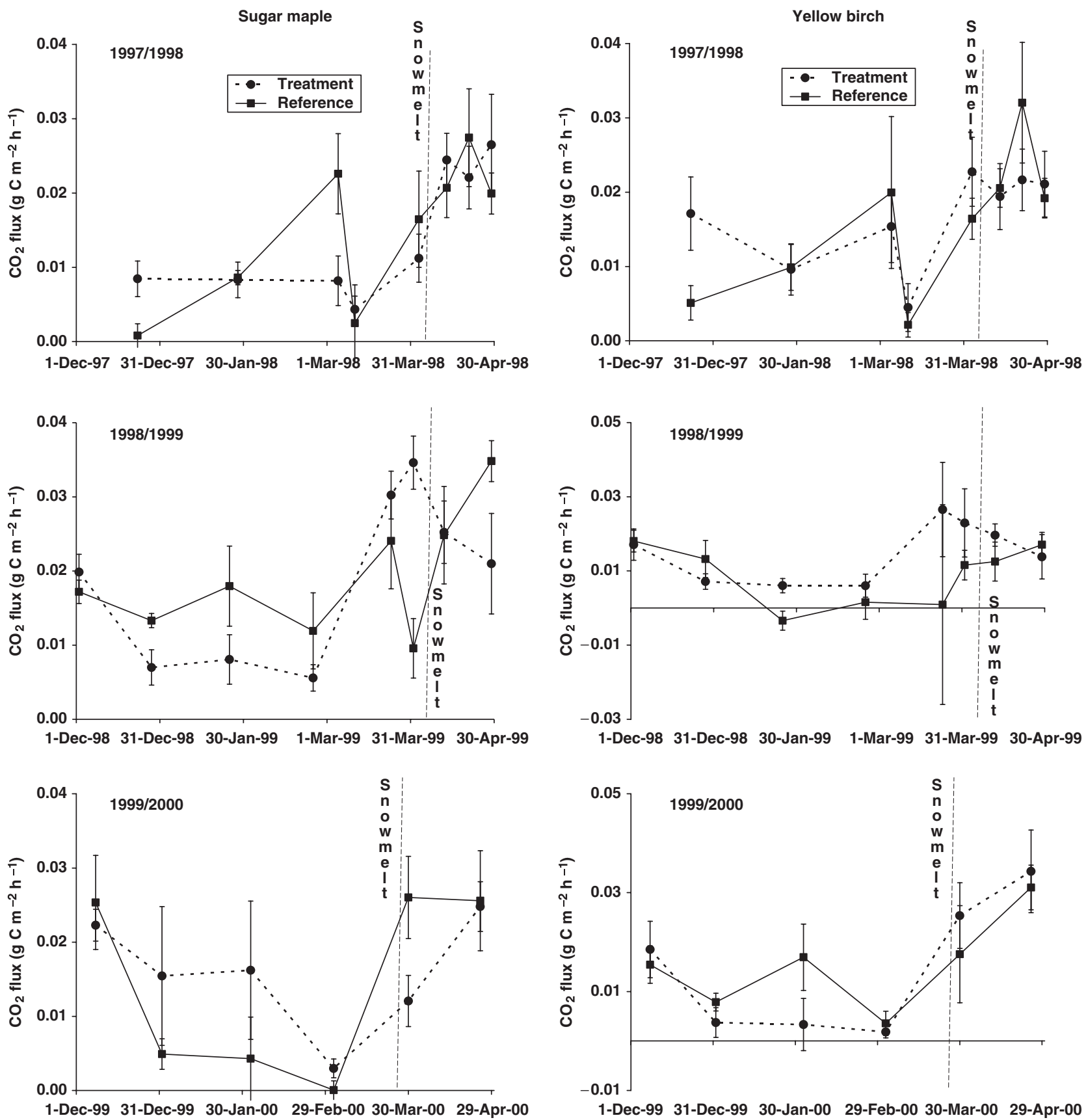

Fig. 2 Carbon dioxide flux in reference and treatment plots in sugar maple (left) and yellow birch (right) stands in the winters of 1997/1998 (top), 1998/1999 (middle) and 1999/2000 (bottom). Shoveling treatments were applied in 1997/1998 and 1998/1999 while $1999 / 2000$ was a nontreatment, 'recovery' year. Values are means of two plots per treatment/vegetation combination $(n=2)$ with standard error. There were three or four flux chambers per plot.

plots and the 'in soil' chambers used for snow-free plots produced similar data. Visual analysis is particularly illustrative around the time of snowmelt, which necessitated a method shift for all plots (snow was allowed to accumulate on the treatment plots after February 1). We observed very few sharp changes in fluxes before and after snowmelt, suggesting that the switch from 'over snow' to 'in soil' chambers did not have a significant effect on our evaluation of rates or patterns of flux.

Fluxes of $\mathrm{N}_{2} \mathrm{O}$ showed no clear seasonal pattern, with production during the winter similar to fluxes during the growing season (Table 2). The shoveling treatment significantly increased $\mathrm{N}_{2} \mathrm{O}$ flux $(P<0.05)$ during winter and during the winter/spring transition period, in both 

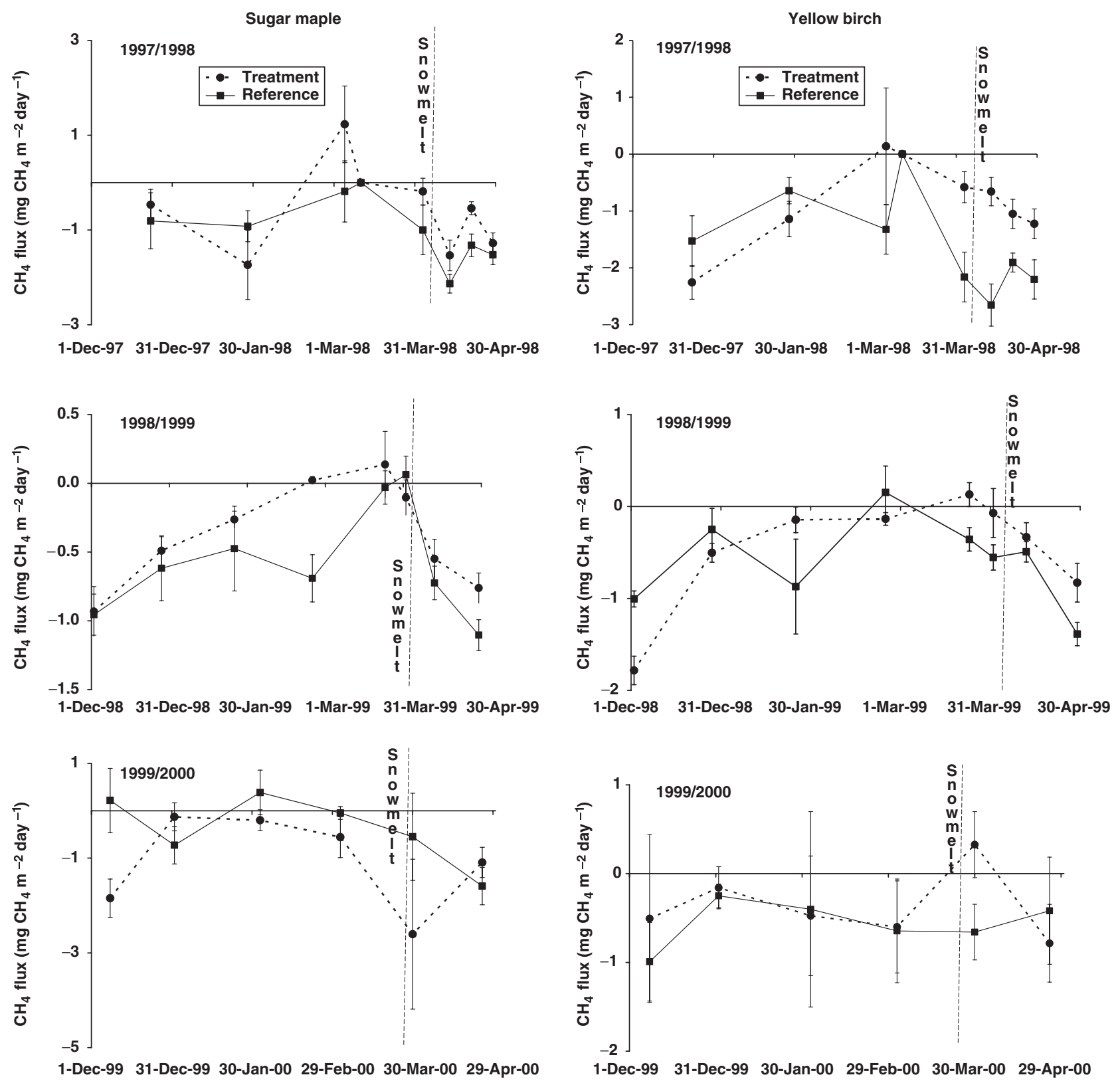

Fig. 3 Methane uptake in reference and treatment plots in sugar maple (left) and yellow birch (right) stands in the winters of 1997/1998 (top), 1998/1999 (middle) and 1999/2000 (bottom). Shoveling treatments were applied in 1997/1998 and 1998/1999 while 1999/2000 was a nontreatment, 'recovery' year. Values are means of two plots per treatment/vegetation combination $(n=2)$ with standard error. There were three or four flux chambers per plot.

sugar maple and yellow birch plots, in both winters of treatment (Fig. 1). There was no difference between treatment and reference plots in the year following treatment $(1999 / 2000)$. Averaged over all plots, winter accounted for $11 \%$ of annual $\mathrm{N}_{2} \mathrm{O}$ flux in $1998,33 \%$ in 1999 and $41 \%$ in 2000.

In contrast to $\mathrm{N}_{2} \mathrm{O}$, fluxes of $\mathrm{CO}_{2}$ showed strong seasonal patterns driven by temperature, with high fluxes during summer and low (but significant) fluxes during winter, and no treatment effect (Table 2, Fig. 2). Winter represented $11 \%, 9 \%$ and $15 \%$ of annual fluxes of $\mathrm{CO}_{2}$ in 1998, 1999 and 2000, respectively.

Similar to $\mathrm{CO}_{2}$, fluxes of $\mathrm{CH}_{4}$ showed strong seasonal patterns driven by temperature, with high fluxes during summer and low (but significant) fluxes during winter (Table 2, Fig. 3). The freeze treatment significantly $(P<0.05)$ reduced $\mathrm{CH}_{4}$ uptake during the winter/ spring transition period just around snowmelt, in both

(C) 2006 The Authors

Journal compilation (C) 2006 Blackwell Publishing Ltd, Global Change Biology, 12, 1748-1760 
Table 2 Mean seasonal fluxes of $\mathrm{CO}_{2}, \mathrm{~N}_{2} \mathrm{O}$ and $\mathrm{CH}_{4}$ in 1998, 1999 and 2000

\begin{tabular}{lccr}
\hline & 1998 & 1999 & \multicolumn{1}{c}{2000} \\
\hline $\mathrm{CO}_{2}\left(\mathrm{mg} \mathrm{C} \mathrm{m}^{-2} \mathrm{~h}^{-1}\right)$ & & \\
Winter & $9(2)$ & $13(2)$ & $12(2)$ \\
Spring & $21(2)$ & $20(3)$ & $26(2)$ \\
Summer & $54(4)$ & $108(5)$ & $48(8)$ \\
Fall & $32(5)$ & $51(13)$ & $37(3)$ \\
$\mathrm{N}_{2} \mathrm{O}\left(\mathrm{ng} \mathrm{N} \mathrm{cm}{ }^{-2} \mathrm{~h}^{-1}\right)$ & & \\
Winter & $0.67(0.43)$ & $0.88(0.18)$ & $0.63(0.22)$ \\
Spring & $1.58(0.22)$ & $1.04(0.25)$ & $-0.12(0.66)$ \\
Summer & $3.22(0.22)$ & $1.05(0.21)$ & $1.89(0.74)$ \\
Fall & $2.25(0.42)$ & $0.67(0.17)$ & $1.06(0.28)$ \\
$\mathrm{CH}_{4}\left(\mathrm{mg} \mathrm{CH} \mathrm{C}_{4} \mathrm{~m}^{-2} \mathrm{day}\right)$ & & \\
Winter & $-0.77(0.23)$ & $-0.43(0.09)$ & $-0.48(0.15)$ \\
Spring & $-1.37(0.14)$ & $-0.56(0.10)$ & $-1.28(0.15)$ \\
Summer & $-2.26(0.17)$ & $-1.73(0.09)$ & $-1.71(0.12)$ \\
Fall & $-1.55(0.27)$ & $-0.68(0.23)$ & $-1.87(0.29)$ \\
\hline
\end{tabular}

Values are the means (standard error) of all fluxes measured during winter (December-March), spring (April-May), summer (June-August) and fall (September-November) in treatment and reference plots in two sugar maple and two yellow birch stands, $n=16-40$.

sugar maple and yellow birch plots, in both winters of treatment (Fig. 1). There was no difference between treatment and reference plots in the year following treatment (1999/2000). Winter represented 18\%, 17\% and $13 \%$ of annual fluxes of $\mathrm{CH}_{4}$ in 1998, 1999 and 2000, respectively.

Correlations between gas flux and soil temperature were higher for $\mathrm{CO}_{2}(r=0.75, P<0.001)$ and $\mathrm{CH}_{4}$ $(r=0.51, P<0.001)$ than for $\mathrm{N}_{2} \mathrm{O}(r=0.31, P<0.001)$. There were no significant correlations between any gas flux and soil moisture. Soil moisture was consistently higher in the reference plots compared with the treatment plots during winter (Fig. 4), which was consistent with the snow (moisture) removal treatment and with leachate collections during the winter period (Hardy et al., 2001) but may also have been caused by the limited ability of water content reflectometers to accurately measure the water content of frozen soil (Seyfried \& Murdock, 1996).

Annual flux of $\mathrm{N}_{2} \mathrm{O}$ (Fig. 5 - top) was increased by the shoveling treatment in $1998(P<0.13)$ and significantly in $1999(P<0.02)$. There was significant $(P<0.05)$ annual variation in $\mathrm{N}_{2} \mathrm{O}$ flux, with higher fluxes in 1998 than in 1999 or 2000. High fluxes in 1998 were driven by high activity in summer and fall (Table 2). There was no vegetation effect on $\mathrm{N}_{2} \mathrm{O}$ fluxes.

There was no treatment or vegetation effect on annual $\mathrm{CO}_{2}$ flux, but fluxes were significantly $(P<0.05)$ higher in 1999 than in 1998 and 2000 (Fig. 5 - middle). High fluxes in 1999 were driven by high activity in summer and fall (Table 2).

There was no treatment effect on annual $\mathrm{CH}_{4}$ flux, but uptake (negative fluxes) was significantly higher in yellow birch than in sugar maple in both 1998 $(P<0.02)$ and $1999(P<0.10)$ (Fig. 5 - bottom). $\mathrm{CH}_{4}$ uptake was significantly lower $(P<0.05)$ in 1999 than in 1998 or 2000, due primarily to low fluxes in spring and fall of 1999 (Table 1).

\section{Discussion}

$\mathrm{N}_{2} \mathrm{O}$

At first glance, it is not surprising that our snow manipulation treatment increased $\mathrm{N}_{2} \mathrm{O}$ fluxes. The treatment disrupted ecosystem $\mathrm{N}$ cycling and greatly increased $\mathrm{NO}_{3}^{-}$leaching (Fitzhugh et al., 2001, Table 1), and many studies have shown that this type of disruption increases $\mathrm{N}_{2} \mathrm{O}$ fluxes (Groffman et al., 2000). A more in-depth analysis, however, raises some interesting mechanistic questions. Note that the treatment increased $\mathrm{NO}_{3}^{-}$leaching but had no effect on microbial biomass or net mineralization and nitrification or denitrification rates (Groffman et al., 2001b, Table 1), suggesting that the increase in leaching was caused by a reduction in plant uptake, a conclusion that is supported by the increase in overwinter fine root mortality associated with the treatment (Tierney et al., 2001, Table 1). The increased $\mathrm{N}_{2} \mathrm{O}$ fluxes that we observed were therefore not associated with microbial mortality and a 'flush' of nitrification, denitrification and $\mathrm{N}_{2} \mathrm{O}$ release as has been observed in some other studies (Edwards \& Killham, 1986; Christensen \& Tiedje, 1990; DeLuca et al., 1992; Schimel \& Clein, 1996). Release of $\mathrm{N}_{2} \mathrm{O}$ trapped beneath ice layers in the soil, another mechanism by which soil freezing has been reported to increase $\mathrm{N}_{2} \mathrm{O}$ flux (Goodroad \& Keeney, 1984; Burton \& Beauchamp, 1994; van Bochove et al., 2001), also did not appear to be a major factor in our study, as we did not observe any marked 'bursts' of production, and there was no increase in $\mathrm{CO}_{2}$ flux during winter or spring. Freezing in our soils was 'granular' rather than 'concrete (as is common in agricultural soils)' and, therefore, not a major barrier to diffusion (Hardy et al., 2001). However, it is possible that our sampling was not frequent, or keyed to thaw events enough to detect these bursts.

We suggest that increased $\mathrm{N}_{2} \mathrm{O}$ flux in response to our treatment was driven by increased levels of inorganic $\mathrm{N}$ in the soil associated with reduced plant uptake. As ammonium $\left(\mathrm{NH}_{4}^{+}\right)$and $\mathrm{NO}_{3}^{-}$are produced in the soil, they are subject to multiple fates - plant uptake, leaching and nitrification and denitrification, with associated 

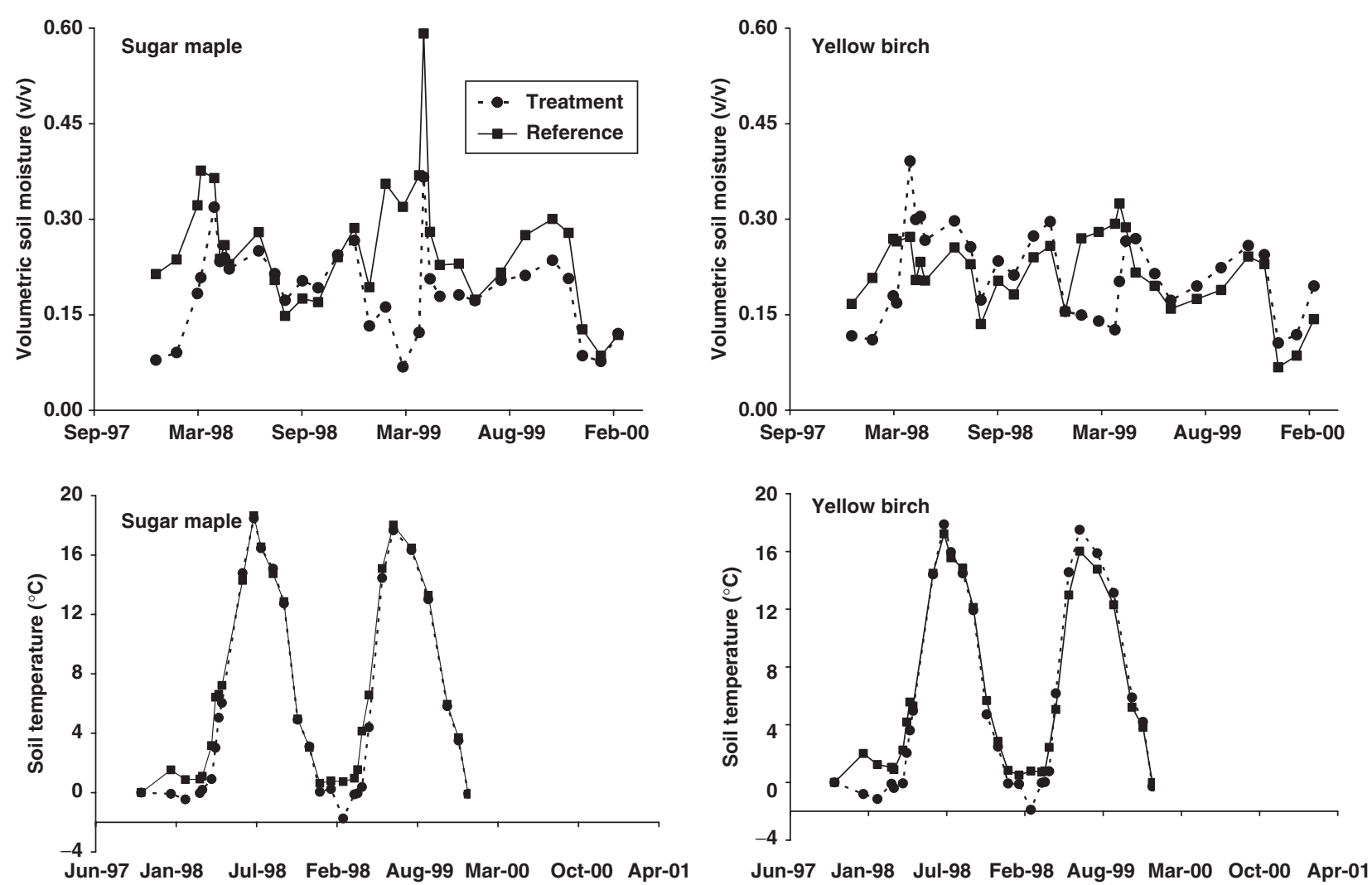

Fig. 4 Volumeteric soil moisture (top) in the Oa horizon and soil temperature at $10 \mathrm{~cm}$ depth (bottom) in reference and treatment plots in sugar maple (left panels) and yellow birch (right panels) stands from fall 1997 to spring 2000. Values are means of two plots per treatment/vegetation combination $(n=2)$ with standard error. There were two time domain reflectometry probes and thermistors per plot. Data adapted from Hardy et al. (2001).

$\mathrm{N}_{2} \mathrm{O}$ production (Zak et al., 1990; Groffman et al., 1993). Even though we did not observe significant increases in nitrification and denitrification there was clearly an increase in soil inorganic $\mathrm{N}$ levels and leaching, which likely led to enough of an increase in nitrification and denitrification to account for the increased $\mathrm{N}_{2} \mathrm{O}$ flux that we observed. The increase in $\mathrm{N}_{2} \mathrm{O}$ flux (approximately $1 \mathrm{~kg} \mathrm{Nha}^{-1} \mathrm{yr}^{-1}$ ) was small relative to net mineralization and nitrification (70-210 $\mathrm{kg} \mathrm{Nha}^{-1} \mathrm{yr}^{-1}$ ), and well within the error estimates of these processes. It is also possible that increased levels of inorganic $\mathrm{N}$, or lower soil moisture, altered the product ratios $\left(\mathrm{NO}: \mathrm{N}_{2} \mathrm{O}: \mathrm{N}_{2}\right)$ during denitrification to favor $\mathrm{N}_{2} \mathrm{O}$ (Davidson \& Verchot, 2000), leading to an increase in $\mathrm{N}_{2} \mathrm{O}$ flux with no increase in net mineralization, nitrification or denitrification rates.

It is somewhat surprising that the treatment effect on $\mathrm{N}_{2} \mathrm{O}$ flux was not more marked in sugar maple than yellow birch plots, as the treatment effect on $\mathrm{NO}_{3}^{-}$ leaching was much more marked in sugar maple-dominated plots (Fitzhugh et al., 2001). The fact that the increase in $\mathrm{N}_{2} \mathrm{O}$ flux was small relative to other $\mathrm{N}$ fluxes may explain the lack of vegetation effect. It is also possible that complex differences in $\mathrm{C}$ and $\mathrm{N}$ dynamics between sugar maple and yellow birch (Nielsen et al., 2001) have balancing effects on the nitrification and denitrification processes that produce $\mathrm{N}_{2} \mathrm{O}$, resulting in no net difference.

While winter fluxes of $\mathrm{N}_{2} \mathrm{O}$ were as important as fluxes during warmer periods of the year, the annual fluxes were not dominated by the winter period as has been observed in some other sites (Brumme et al., 1999). In contrast, we observed significant variation in annual $\mathrm{N}_{2} \mathrm{O}$ flux that was driven primarily by high fluxes during the summer and fall of 1998 . The cause of this variation is difficult to explain given our limited sampling regime (monthly) during summer.

While the $\mathrm{N}_{2} \mathrm{O}$ fluxes that we measured are small relative to other $\mathrm{N}$ fluxes in the ecosystem, they are high relative to other $\mathrm{N}_{2} \mathrm{O}$ flux estimates for forests in the northeastern US, and potentially important in a regional context. In previous work at the HBEF, Keller et al. (1983) reported much lower summer $\mathrm{N}_{2} \mathrm{O}$ flux $\left(0.17 \mathrm{ng} \mathrm{cm}^{-2} \mathrm{~h}^{-1}\right)$ than we observed (from 1.05 to $3.22 \mathrm{ng} \mathrm{cm}^{-2} \mathrm{~h}^{-1}$ ). The Keller et al. (1983) measurements were likely lower than ours because they were not 

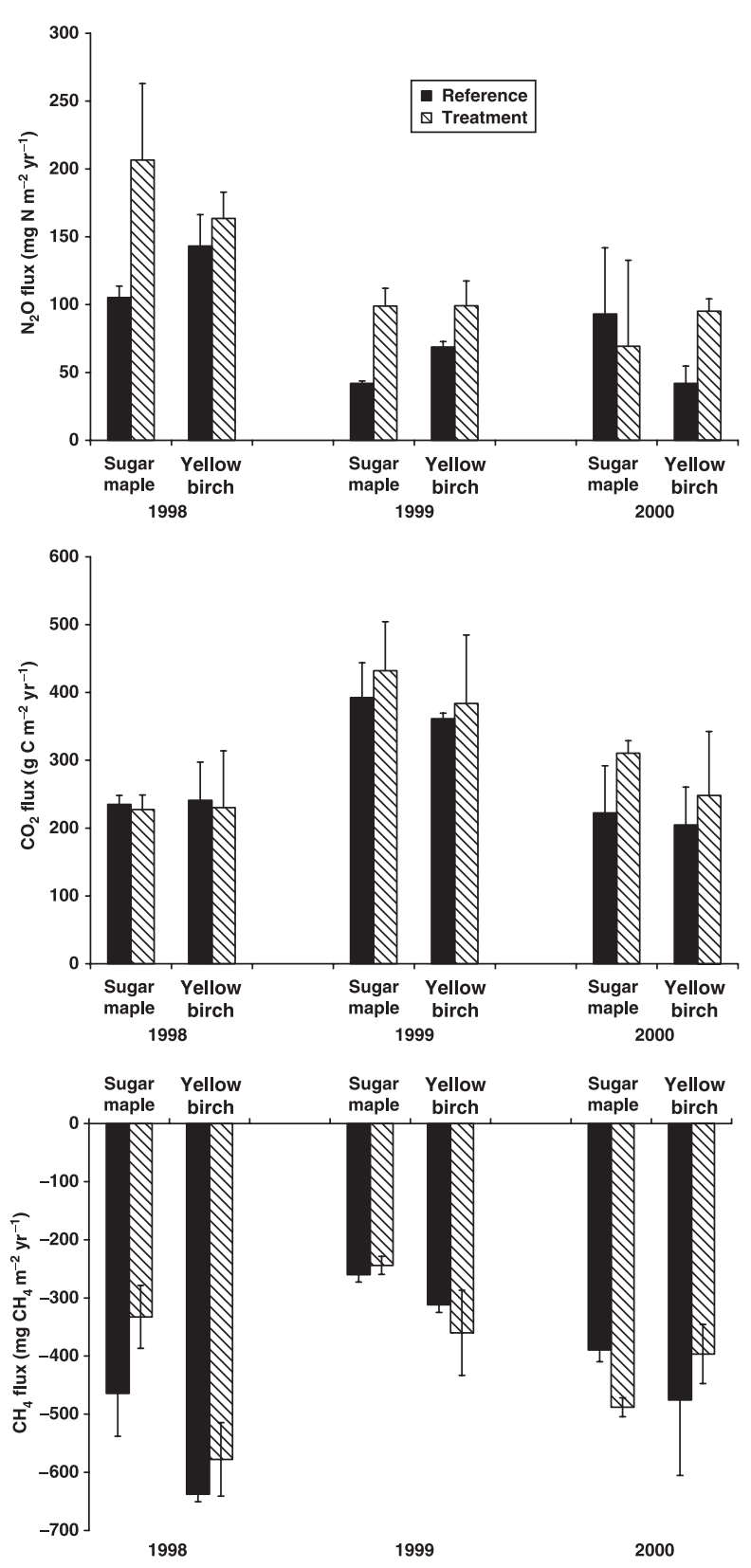

Fig. 5 Annual nitrous oxide (top), carbon dioxide (middle) and methane (bottom) flux in reference and treatment plots in sugar maple and yellow birch stands in 1998, 1999 and 2000. Values are means of two plots per treatment/vegetation combination $(n=2)$ with standard error.

focused on sugar maple and yellow birch (species associated with high rates of $\mathrm{N}$ cycling; Lovett et al., 2004) stands as ours were, and the forest at HBEF was younger and growing more rapidly (and cycling $\mathrm{N}$ more tightly) then. Bowden \& Bormann (1986) reported that $\mathrm{N}_{2} \mathrm{O}$ flux in drainage water increased in response to clear cutting at the HBEF, but the total flux was low (30 $\mathrm{mg} \mathrm{N} \mathrm{m}^{-2}$ ) compared with our flux estimates (up to
$200 \mathrm{mg} \mathrm{N} \mathrm{m}^{-2} \mathrm{yr}^{-1}$ ). Many studies of $\mathrm{N}_{2} \mathrm{O}$ flux at the Harvard Forest (approximately $200 \mathrm{~km}$ from the HBEF), using the same methods that we use, have suggested that these fluxes are very low $\left(<1.0 \mathrm{ng} \mathrm{cm}^{-2} \mathrm{~h}^{-1}\right)$ relative to the fluxes we measured at the HBEF and not responsive to fertilization, soil warming or canopy tree blowdown (Bowden et al., 1990, 1991, 1993; Peterjohn et al., 1994; Venterea et al., 2003). The Harvard Forest sites are dominated by oak and pine species that are associated with low rates of $\mathrm{N}$ cycling compared with sugar maple and yellow birch (Lovett et al., 2004). The fluxes we measured are similar to those measured at relatively N-rich sites in West Virginia (Peterjohn et al., 1998; Venterea et al., 2004) and Pennsylvania (Bowden et al., 2000), but are lower than fluxes in highly $\mathrm{N}$ saturated forests in Europe (Brumme et al., 1999; Groffman et al., 2000; Butterbach-Bahl et al., 2002).

The highest $\mathrm{N}_{2} \mathrm{O}$ fluxes that we measured (nearly $200 \mathrm{mg} \mathrm{N} \mathrm{m}^{-2} \mathrm{yr}^{-1}$ ) are potentially important relative to atmospheric deposition of $\mathrm{N}$, an important driver of $\mathrm{N}$ dynamics at the regional scale in the northeastern US (Aber et al., 1998). Given that deposition is less than $1000 \mathrm{mg} \mathrm{N} \mathrm{m}^{-2} \mathrm{yr}^{-1}$ at the HBEF and in many parts of the northeastern US, our results suggest that approximately $25 \%$ of this deposition input may be offset by $\mathrm{N}_{2} \mathrm{O}$ flux from soil to the atmosphere. This flux is, thus, high enough to be considered when setting 'critical loads' for $\mathrm{N}$ deposition in this region (Driscoll et al., 2003).

$\mathrm{CO}_{2}$

Our results support previous observations that soilatmosphere $\mathrm{CO}_{2}$ flux occurs during winter, and in frozen soils (Sommerfield et al., 1993; Clein \& Schimel, 1995; Brooks et al., 1997; Alm et al., 1999; van Bochove et al., 2000b). However, winter fluxes of $\mathrm{CO}_{2}$ were much less important to the annual flux of this gas than for $\mathrm{N}_{2} \mathrm{O}$. This pattern is likely because of the fact that one of the two primary processes of soil $\mathrm{CO}_{2}$ production, root respiration, is likely small during winter. Given that root respiration represents a significant proportion of total soil respiration, it is likely that a significant portion of microbial respiration occurs during winter, but its importance is masked by the seasonal variation in plant activity. It is also likely that temperature effects on $\mathrm{CO}_{2}$ flux are more obvious than effects on $\mathrm{N}_{2} \mathrm{O}$ flux because the regulation of the processes behind $\mathrm{N}_{2} \mathrm{O}$ flux are much more complex.

Our estimates of respiration were low relative to other measurements at the HBEF and at other forest sites in the northeastern US. Fahey et al. (2005) report total soil respiration ranging from 540 to $800 \mathrm{~g} \mathrm{C} \mathrm{m}^{-2} \mathrm{yr}^{-1}$ in eight stands at the HBEF sampled from 1998 to 2000, 
higher than our estimates which ranged from 230 to $400 \mathrm{~g} \mathrm{C} \mathrm{m}^{-2} \mathrm{yr}^{-1}$. Savage \& Davidson (2001) reported soil respiration rates of greater than $500 \mathrm{gC} \mathrm{m}^{-2} \mathrm{yr}^{-1}$ from upland sites at the Harvard Forest and greater than $800 \mathrm{~g} \mathrm{C} \mathrm{m}^{-2} \mathrm{yr}^{-1}$ from upland sites at the Howland Forest in Maine. In contrast to our findings, these authors reported lower respiration in 1999 than in 1998, due to lower soil moisture in 1999, which we did not observe at HBEF. The fact that their estimates were based on more high-resolution sampling, which captures episodes of high flux that are missed with our less frequent sampling (Parkin \& Kaspar, 2004), may also contribute to the difference. Of likely greater importance is the fact that both Fahey et al. (2005) and Savage \& Davidson (2001) made measurements over much shorter time periods than we did ( $1-5$ vs. $30 \mathrm{~min}$ ). Accumulation of high concentrations of $\mathrm{CO}_{2}$ in our chambers likely inhibited flux from the soil (Holland et al., 1999). Comparison of our chamber method with the method used by Fahey et al. (2005) on our plots found consistently lower flux measurements with our method (P. M. Groffman \& T. J. Fahey, unpublished data).

\section{$\mathrm{CH}_{4}$}

As expected, $\mathrm{CH}_{4}$ flux responded to our snow manipulation treatment, but the effect was restricted to the period just before and immediately after snowmelt. The treatment clearly altered $\mathrm{N}$ cycling, and this flux has been shown to be responsive to increases in $\mathrm{N}$ availability (especially soil inorganic $\mathrm{N}$ levels) in many studies (Steudler et al., 1989; Mosier et al., 1991). It is somewhat surprising that the treatment effect on $\mathrm{CH}_{4}$ uptake did not persist into the growing season, as leaching losses were increased by the treatment throughout the summer. However, interactions between $\mathrm{N}$ cycling and $\mathrm{CH}_{4}$ uptake have proven to be more complex than first thought, and it is difficult to predict $\mathrm{CH}_{4}$ fluxes given information on ecosystem $\mathrm{N}$ cycling (Castro et al., 1995; Reay \& Nedwell, 2004). While the treatment increased leaching losses of $\mathrm{N}$ in our study, rates of net mineralization and nitrification during the growing season were not affected, so it may not be surprising that $\mathrm{CH}_{4}$ flux was not affected.

In contrast to our results, Borken et al. (2006) found that snow removal increased rates of $\mathrm{CH}_{4}$ uptake in temperate forest soils. However, their snow removal treatment did not result in soil freezing or stimulation of $\mathrm{N}$ cycling. Rather, it enhanced diffusion of $\mathrm{CH}_{4}$ from the atmosphere into the soil, leading to increased methanotroph activity.

The $\mathrm{CH}_{4}$ uptake rates that we observed were similar to those measured at other forested sites in the northeastern US (Castro et al., 1995), including previous measurements at HBEF (Keller et al., 1983). Forests in the northeastern US tend to have high $\mathrm{CH}_{4}$ uptake relative to forests in other parts of the world (Smith et al., 2000).

The significant differences in $\mathrm{CH}_{4}$ uptake between plots dominated by different tree species (yellow birch greater than sugar maple) that we observed is consistent with other studies showing that tree species can have significant effects on this flux (Butterbach-Bahl \& Papen, 2002; Borken et al., 2003; Menyailo \& Hungate, 2003). The mechanisms behind these effects are complex, as $\mathrm{CH}_{4}$ flux is affected by the balance between production and consumption of this gas, physical factors that influence gas diffusion, and the above-mentioned complex links with $\mathrm{N}$ cycling. In our study, plots dominated by yellow birch tend to have high $\mathrm{C}$, and low $\mathrm{N}$ availability to microbes relative to plots dominated by sugar maple (Nielsen et al., 2001), which may be driving the differences in $\mathrm{CH}_{4}$ flux that we observed.

\section{Implications for climate change}

Our results suggest that in a warmer world with less snow and more soil freezing, $\mathrm{N}_{2} \mathrm{O}$ emissions from northern hardwood forest soils may increase, perhaps by as much as twofold. And these fluxes are important, equal to a significant percentage of atmospheric $\mathrm{N}$ deposition. Brumme et al. (1999) classified forest ecosystems into three $\mathrm{N}_{2} \mathrm{O}$ emission classes: 'background' sites with very low emissions and 'event (primarily freeze/thaw events)-based' and 'seasonal' emission classes with much higher fluxes. Climate change that results in increased soil freezing will push forests like those at the HBEF from the 'background' to the 'eventbased' class. It should be possible to use regional-scale forest databases and climate change scenarios to determine just how widespread this conversion will be, and what effect it will have on regional and global $\mathrm{N}_{2} \mathrm{O}$ budgets. These evaluations will also have to consider climate change effects on $\mathrm{N}_{2} \mathrm{O}$ fluxes during the growing season, which could either amplify or dampen the effects of changes in climatic conditions during winter. In addition to effects on $\mathrm{N}_{2} \mathrm{O}, \mathrm{CH}_{4}$ uptake was reduced by the treatment, suggesting that in a warmer world with less snow and more soil freezing, the capacity of northern hardwood forests to remove this greenhouse gas from the atmosphere will be reduced.

Our results support the idea that tree species are strong regulators of biogeochemical processes in forests (Lovett et al., 2004). Understanding relationships between species and trace gas fluxes should be useful as a tool for landscape and regional-scale assessments of flux, and for understanding how these fluxes will change with climate. 


\section{Acknowledgements}

We thank Adam Welman, Jason Demers, Lisa Martel and Sabrina LaFave for excellent field, laboratory and data analysis work. This research was supported by US National Science Foundation Grants DEB-9652678 (a product of the interagency program on Terrestrial Ecosystems and Global Change (TECO)), DEB 9810221 (Hubbard Brook Long Term Ecological Research) and DEB 00-75387 (Ecosystem Studies). This research was conducted at the Hubbard Brook Experimental Forest, which is operated by the Northeastern Research Station, USDA Forest Service, Newtown Square, PA. This paper is a contribution to the Hubbard Brook Ecosystem Study.

\section{References}

Aber J, McDowell W, Nadelhoffer K et al. (1998) Nitrogen saturation in temperate forest ecosystems: hypothesis revisited. BioScience, 48, 921-934.

Alm J, Saarnio AJ, Nykanen $\mathrm{H}$ et al. (1999) Winter $\mathrm{CO}_{2}, \mathrm{CH}_{4}$ and $\mathrm{N}_{2} \mathrm{O}$ fluxes on some natural and drained boreal peatlands. Biogeochemistry, 44, 163-186.

Borken W, Davidson EA, Savage K et al. (2006) Effect of summer throughfall exclusion, summer drought, and winter snow cover on methane fluxes in a temperate forest soil. Soil Biology and Biochemistry, 38, 1388-1395.

Borken W, Yu YJ, Beese F (2003) Conversion of hardwood forests to spruce and pine plantations strongly reduced soil methane sink in Germany. Global Change Biology, 9, 956-966.

Bowden R, Melillo J, Steudler P et al. (1991) Effects of nitrogen additions on annual nitrous oxide fluxes from temperate forest soils in the northeastern United States. Journal of Geophysical Research - Atmospheres, 96, 9321-9328.

Bowden R, Steudler P, Melillo J et al. (1990) Annual nitrous oxide fluxes from temperate forest soils in the northeastern United States. Journal of Geophysical Research - Atmospheres, 95, 13,997-14,005.

Bowden RD, Castro MS, Melillo JM et al. (1993) Fluxes of greenhouse gases between soils and the atmosphere in a temperate forest following a simulated hurricane blowdown. Biogeochemistry, 21, 61-71.

Bowden RD, Rullo G, Stevens GR et al. (2000) Soil fluxes of carbon dioxide, nitrous oxide, and methane at a productive temperate deciduous forest. Journal of Environmental Quality, 29, 268-276.

Bowden WB, Bormann FH (1986) Transport and loss of nitrous oxide in soil water after forest clear-cutting. Science, 233, 867-869.

Brooks PD, McKnight D, Elder K (2004) Carbon limitation of soil respiration under winter snowpacks: potential feedbacks between growing season and winter carbon fluxes. Global Change Biology, 11, 231-238.

Brooks PD, Schmidt SK, Williams MW (1997) Winter production of $\mathrm{CO}_{2}$ and $\mathrm{N}_{2} \mathrm{O}$ from alpine tundra: environmental controls and relationship to inter-system $\mathrm{C}$ and $\mathrm{N}$ fluxes. Oecologia, 110, 403-413.

Brooks PD, Williams MW, Schmidt SK (1996) Microbial activity under alpine snowpacks, Niwot Ridge, Colorado. Biogeochemistry, 32, 93-113.
Brumme R, Borken W, Finke S (1999) Hierarchical control on nitrous oxide emission in forest ecosystems. Global Biogeochemical Cycles, 13, 1137-1148.

Burton DL, Beauchamp EG (1994) Profile nitrous oxide and carbon dioxide concentrations in a soil subject to freezing. Soil Science Society of America Journal, 58, 115-122.

Butterbach-Bahl K, Gasche R, Willibald G et al. (2002) Exchange of N-gases at the Hoglwald forest - a summary. Plant and Soil, 240, 117-123.

Butterbach-Bahl K, Papen H (2002) Four years continuous record of $\mathrm{CH}_{4}$-exchange between the atmosphere and untreated and limed soil of an N-satured spruce and beech forest ecosystem in Germany. Plant Soil, 240, 77-90.

Castro MS, Steudler PA, Melillo JM et al. (1995) Factors controlling atmospheric methane consumption by temperate forest soils. Global Biogeochemical Cycles, 9, 1-10.

Christensen S, Tiedje JM (1990) Brief and vigorous $\mathrm{N}_{2} \mathrm{O}$ production by soil at spring thaw. Journal of Soil Science, 41, 1-4.

Clein JS, Schimel JP (1995) Microbial activity of tundra and taiga soils at sub-zero temperatures. Soil Biology and Biochemistry, 27, 1231-1234.

Davidson EA, Verchot LV (2000) Testing the hole-in-the-pipe model of nitric and nitrous oxide emissions from soils using the TRAGNET database. Global Biogeochemical Cycles, 14, 1035-1043.

DeLuca TH, Keeney DR, McCarty GW (1992) Effect of freezethaw events on mineralization of soil nitrogen. Biology and Fertility of Soils, 14, 116-120.

Dörsch P, Palojäri A, Mommertz S (2004) Overwinter greenhouse gas fluxes in two contrasting agricultural habitats. Nutrient Cycling in Agroecosystems, 70, 117-133.

Driscoll C, Whitall D, Aber J et al. (2003) Nitrogen pollution in the northeastern United States: sources, effects and management options. BioScience, 53, 357-374.

Dye DG (2002) Variability and trends in the annual snow-cover cycle in Northern Hemisphere land areas, 1972-2000. Hydrological Processes, 16, 305-3077.

Edwards AC, Killham K (1986) The effect of freeze/thaw on gaseous nitrogen loss from upland soils. Soil Use Management, 2, 86-91.

Fahey TJ, Tierney GL, Fitzhugh RD et al. (2005) Soil respiration and soil carbon balance in a northern hardwood forest ecosystem. Canadian Journal of Forest Research, 35, 244-253.

Fitzhugh RD, Driscoll CT, Groffman PM et al. (2001) Effects of soil freezing disturbance on soil solution nitrogen, phosphorus, and carbon chemistry in a northern hardwood ecosystem. Biogeochemistry, 56, 215-238.

Fitzhugh RD, Driscoll CT, Groffman PM et al. (2003) Soil freezing and the acid-base chemistry of soil solutions in a northern hardwood forest. Soil Science Society of America Journal, 67, 1897-1908.

Goodroad LL, Keeney DR (1984) Nitrous oxide emissions from soils during thawing. Canadian Journal of Soil Science, 64, 187-194.

Groffman PM, Brumme R, Butterbach-Bahl K et al. (2000) Evaluating annual nitrous oxide fluxes at the ecosystem scale. Global Biogeochemical Cycles, 14, 1061-1070.

Groffman PM, Driscoll CT, Fahey TJ et al. (2001a) Colder soils in a warmer world: a snow manipulation study in 
a northern hardwood forest ecosystem. Biogeochemistry, $\mathbf{5 6}$ 135-150.

Groffman PM, Driscoll CT, Fahey TJ et al. (2001b) Effects of mild winter freezing on soil nitrogen and carbon dynamics in a northern hardwood forest. Biogeochemistry, 56, 191-213.

Groffman PM, Tiedje JM (1989) Denitrification in north temperate forest soils: spatial and temporal patterns at the landscape and seasonal scales. Soil Biology and Biochemistry, 21, 613-620.

Groffman PM, Zak DR, Christensen S et al. (1993) Early spring nitrogen dynamics in a temperate forest landscape. Ecology, 74, 1579-1585.

Hardy JP, Groffman PM, Fitzhugh RD et al. (2001) Snow depth, soil frost and water dynamics in a northern hardwood forest. Biogeochemistry, 56, 151-174.

Hodgkins GA, Dudley RW, Huntington TG (2003) Changes in the timing of high river flows in New England over the 20th century. Journal of Hydrology, 278, 244-252.

Holland EA, Boone R, Greenberg J et al. (1999) Measurement of soil $\mathrm{CO}_{2}, \mathrm{~N}_{2} \mathrm{O}$ and $\mathrm{CH}_{4}$ exchange. In: Standard Soil Methods for Long Term Ecological Research (eds Robertson GP, Bledsoe CS, Coleman DC, Sollins P), pp. 272-288. Oxford University Press, New York.

Hubbard RM, Ryan MG, Elder K et al. (2005) Seasonal patterns in soil surface $\mathrm{CO}_{2}$ flux under snow cover in 50 and 200 year old subalpine forests. Biogeochemistry, 73, 93-107.

Keller M, Goreau TJ, Wofsy SC et al. (1983) Production of nitrous oxide and consumption of methane by forest soils. Geophysical Research Letters, 10, 1156-1159.

Likens GE (2000) A long-term record of ice-cover for Mirror Lake, NH: effects of global warming? Verhandlunden der internationale Vereinigung für theoretische und angewandte Limnologie, 27, 2765-2769.

Lovett GM, Weathers KC, Arthur MA et al. (2004) Nitrogen cycling in a northern hardwood forest: do species matter? Biogeochemistry, 67, 289-308.

Melloh RA, Crill PM (1996) Winter methane dynamics in a temperate fen. Global Biogeochemical Cycles, 10, 247-254.

Menyailo OV, Hungate BA (2003) Interactive effects of tree species and soil moisture on methane consumption. Soil Biology and Biochemistry, 35, 625-628.

Mitchell MJ, Driscoll CT, Kahl JS et al. (1996) Climatic control of nitrate loss from forested watersheds in the northeast United States. Environmental Science and Technology, 30, 2609-2612.

Mooney HA, Vitousek PM, Matson PA (1987) Exchange of materials between terrestrial ecosystems and the atmosphere. Science, 238, 926-932.

Mosier A, Schimel D, Valentine D et al. (1991) Methane and nitrous oxide fluxes in native, fertilized and cultivated grasslands. Nature, 350, 330-332.

Murdoch PS, Burns DA, Lawrence GB (1998) Relation of climate change to the acidification of surface waters by nitrogen deposition. Environmental Science and Technology, 32, 1642-1647.

Nielsen CB, Groffman PM, Hamburg SP et al. (2001) Freezing effects on carbon and nitrogen cycling in soils from a northern hardwood forest. Soil Science Society of America Journal, 65, 1723-1730.
Parkin TB, Kaspar TC (2004) Temporal variability of soil carbon dioxide flux: effect of sampling frequency on cumulative carbon loss estimation. Soil Science Society of America Journal, 58, 1234-1241.

Peterjohn WT, McGervey RJ, Sexstone AJ et al. (1998) Nitrous oxide production in two forested watersheds exhibiting symptoms of nitrogen saturation. Canadian Journal of Forest Research, 28, 1723-1732.

Peterjohn WT, Melillo JM, Steudler PA et al. (1994) Responses of trace gas fluxes and $\mathrm{N}$ availability to experimentally elevated soil temperatures. Ecological Applications, 4, 617-625.

Prather M, Derwent R, Ehhalt D et al. (1995) Other trace gases and atmospheric chemistry. In: Climate Change 1994: Radiative Forcing of Climate Changes and an Evaluation of the IPCC IS92 Emission Scenarios (eds Houghton J, Meira LG, Haites E, Harris N, Maskell K), pp. 73-126. Cambridge University Press, New York.

Reay DS, Nedwell DB (2004) Methane oxidation in temperate soils: effects of inorganic N. Soil Biology and Biochemistry, 36, 2059-2065.

SAS (1989) SAS/STAT User's Guide, Release 6.03. SAS Institute Incorporated, Cary, NC.

Savage KE, Davidson EA (2001) Interannual variation of soil respiration in two New England forests. Global Biogeochemical Cycling, 15, 337-350.

Schimel JP, Bilbrough C, Welker JA (2004) Increased snow depth affects microbial activity and nitrogen mineralization in two Arctic tundra communities. Soil Biology and Biochemistry, 36, 217-227.

Schimel JP, Clein JS (1996) Microbial response to freeze-thaw cycles in tundra and taiga soils. Soil Biology and Biochemistry, 28, 1061-1066.

Schwartz MD, Reiter BE (2000) Changes in North American spring. International Journal of Climatology, 20, 929-932.

Seyfried MS, Murdock MD (1996) Calibration of time domain reflectometry for measurement of liquid water in frozen soils. Soil Science, 161, 87-98.

Smith KA, Dobbie KE, Ball BC et al. (2000) Oxidation of atmospheric methane in northern European soils, comparison with other ecosystems, and uncertainties in the global terrestrial sink. Global Change Biology, 6, 791-803.

Sommerfield RA, Mosier AR, Musselman RC (1993) $\mathrm{CO}_{2}, \mathrm{CH}_{4}$ and $\mathrm{N}_{2} \mathrm{O}$ flux through a Wyoming snowpack and implications for global budgets. Nature, 361, 140-142.

Steudler PA, Bowden RD, Melillo JM et al. (1989) Influence of nitrogen fertilization on methane uptake in temperate forest soils. Nature, 341, 314-316.

Tierney GL, Fahey TJ, Groffman PM et al. (2001) Soil freezing alters fine root dynamics in a northern hardwood forest. Biogeochemistry, 56, 175-190.

van Bochove E, Jones HG, Bertrand N et al. (2000a) Winter fluxes of greenhouse gases from snow-covered agricultural soil: intra-annual and interannual variations. Global Biogeochemical Cycles, 14, 113-125.

van Bochove E, Prevost D, Pelletier F (2000b) Effects of freezethaw and soil structure on nitrous oxide produced in a clay soil. Soil Science Society of America Journal, 64, 1638-1643. 
van Bochove E, Theriault G, Rochette P et al. (2001) Thick ice layers in snow and frozen soil affecting gas emissions from agricultural soils during winter. Journal of Geophysical Research Atmospheres, 106, 23061-23071.

Venterea RT, Groffman PM, Castro MS et al. (2004) Soil emissions of nitric oxide in two forest watersheds subjected to elevated inputs. Forest Ecology and Management, 196, 335-349.

Venterea RT, Groffman PM, Verchot LV et al. (2003) Nitrogen oxide gas emissions from temperate forest soils receiving long-term nitrogen inputs. Global Change Biology, 9, 346-357.
Williams MW, Brooks PD, Seastedt T (1998) Nitrogen and carbon soil dynamics in response to climate change in a highelevation ecosystem in the Rocky Mountains, USA. Arctic and Alpine Research, 30, 26-30.

Wolfe DW, Schwartz MD, Lakso AN et al. (2005) Climate change and shifts in spring phenology of three horticultural woody perennials in northeastern USA. International Journal of Biometeorology, 49, 303-309.

Zak DR, Groffman PM, Christensen S et al. (1990) The Vernal Dam: plant-microbe competition for nitrogen in northern hardwood forests. Ecology, 71, 651-656. 